\title{
Abbreviations used in the text
}

\section{General}

ILP Independent Labour Party; the ILP had joined with the trade unions to form the Labour Party.

LGB Local Government Board, the Whitehall department responsible for planning and administering the 1911 census. Rt Hon John Burns MP was LGB President.

TNA The National Archives, Kew.

\section{Suffrage}

LSWS London Society for Women's Suffrage. The influential LSWS was run by Pippa Strachey.

NUWSS National Union of Women's Suffrage Societies, formed 1897. NUWSS president was Mrs Fawcett. Suffragists campaigned using constitutional tactics.

WFL Women's Freedom League, formed 1907 as a break-away from WSPU, mainly over internal democracy. Charlotte Despard was president. WFL suffragettes also deployed militancy, increasingly using tactics of non-violent civil disobedience.

WSPU Women's Social and Political Union, formed 1903 by Emmeline Pankhurst. WSPU suffragettes soon initiated militant tactics, masterminded by Emmeline's daughter Christabel.

WTRL Women's Tax Resistance League, formed Oct 1909.

Adult suffrage wanted the vote for all men and women by abolishing the property qualification. The People's Suffrage Federation was formed in 1909. 